\title{
PENAMPILAN KETAHANAN ENAM VARIETAS KACANGTANAH TERHADAP PENGGEREK POLONG (ETIELLA ZINCKENELLA TRIETSCHKE) DI DATARAN TINGGI DAN DATARAN RENDAH BENGKULU
}

\author{
Dwinardi Apriyanto $^{1}$, Burhannudin Toha ${ }^{1}$, Priyatiningsih ${ }^{1}$ \& D. Suryati ${ }^{1}$
}

\begin{abstract}
Resistance performance of six groundnut varieties to Soybean Pod Borer (Etiella zinckenella Treitschke) at high and low elevation in Bengkulu. Soybean pod borer (SPB), Etiella zinckenella Treitschke, often caused serious pod damage and reduced pod yield in several groundnut central in Bengkulu. Field trials were conducted in two locations, Air Dingin (Rejang Lebong, $900 \mathrm{~m}$ asl.) and Kuro Tidur (Bengkulu Utara, $200 \mathrm{~m}$ asl.) to evaluate resistance performance of groundnut varieties to SPB. Six varieties, Jerapah, Kacil, Bison, Pather, Singa dan Singa, were grown in Air Dingin. Five varieties ( as above but minus Sima) were grown in Kuro Tidur. Susceptible local variety was used as control. Varieties were arranged in plots in randomized complete block design (RCBD) replicated three times, in $3 \mathrm{~m} \times 5 \mathrm{~m}$ plots and $20 \mathrm{~cm} \times 30 \mathrm{~cm}$ planting space. Dolomite was applied at doses of 0.333 ton ha- ${ }^{-1}$ in Air Dingin and 3 ton ha $^{-1}$ in Kuro Tidur. Plants were fertilized with N (Urea) - P(TSP) - K (KCl) at the nationally recommended doses $\left(70-125-70 \mathrm{~kg} \mathrm{ha}^{-1}\right)$. Damaged pods and larval density were observed three times at 63 , 77 and 93 day after sowing (SAW). Undamaged pods was weighted at harvest. Data were analyzed with analysis of variance and LSD to separate varietal means. The results revealed that the numbers and percetages of damaged pods incresed with plant age. Four groundnut varieties (Kancil, Panther, Singa and Sima) suffered significantly less pod damage than local variety and the other two (Jerapah and Bison), and therefore they are more resistance than the last three. Regardless of varieties, pod damage was significantly higher in Kuro Tidur than that in Air Dingin. The weight of undamage pods of resistance varieties was significantly higher than that of local, but was not significantly difference from that of Bison and Jerapah, in Air Dingin. In contrast, there was no significant different undamage pod weight between all varieties in Kuro Tidur.
\end{abstract}

Key words: Soybean pod borer, Etiella zinckenella, resisance, groundnut

\section{PENDAHULUAN}

Penggerek polong kedelai (PPK) (Etiella zinckenella) telah lama diketahui sebagai hama utama dan terpenting pada tanaman kedelai (Kalshoven, 1981; Kobayashi \& Oku, 1980; Marwoto et al., 1991). Di Bengkulu E. zinckenella menyebabkan kerusakan berat pada tanaman kacang tanah (Apriyanto et al., 2008; 2009a). Diduga menghilangnya tanaman kedelai yang diganti dengan kacang tanah menyebabkan terjadi perubahan status hama ini pada kacang tanah. Apriyanto et al. (2009b) melaporkan bahwa di laboratorium tidak ada perbedaan lama hidup semua instar larva dan siklus hidup PPK antara larva yang diberi biji pakan kacang tanah dengan yang diberi pakan biji kedelai, tetapi di lapangan ketika tanaman kedelai ditanam bersamaan dengan kacang tanah dalam pola strip cropping kerusakan polong nyata lebih tinggi pada tanaman kedelai dibandingkan dengan pada kacang tanah, menunjukkan bahwa sebenarnya tanaman kedelai lebih menarik bagi ngengat PPK. Apriyanto et al. (2008) menyebutkan kerusakan polong kacang tanah yang mencapai 31 - 48\% di Kabupaten Bengkulu Utara dan $>78 \%$ di Kabupaten Seluma. Di Kecamatan Bermani Ulu, dataran tinggi Rejang Lebong, bahkan petani sering mengalami gagal panen. Varietas Panther dan Sima dari Balai Besar Bioteknologi dan Sumberdaya Genetik (BB-Biogen) Bogor lebih tahan dibandingkan dengan varietas lokal yang sudah lama ditanam petani di Bengkulu (Apriyanto et al., 2009a). Tingkat serangan yang tinggi dalam beberapa tahun terakhir menyebabkan turunnya minat petani di banyak kecamatan di Kabupaten Bengkulu Utara, Seluma dan Rejang Lebong untuk menanam kacang tanah.

\footnotetext{
${ }^{1}$ Departemen Proteksi Tanaman, Fakultas Pertanian, Universitas Bengkulu,

Jl. Raya Kandang Limun Bengkulu 38371. E-mail: dwi_nardi@yahoo.com dan kang_dwi@unib.ac.id
} 
Luka pada polong kacang tanah di lapangan menjadi jalan masuk untuk infeksi Aspergillus flavus dan Aspergillus parasiticus, keduanya memproduksi mycotoxin yaitu aflatoxin yang beracun untuk vertebrata dan manusia. Aflatoxin bersifat karsinogen, menyebabkan kerusakan pada hati semua hewan percobaan dan manusia. Kedua cendawan dilaporkan menginfeksi kacang tanah sejak di lapangan, terutama pada dua kondisi, yaitu pada tanaman yang mengalami cekaman lingkungan dan pada polong yang dirusak oleh serangga (Hill et al., 1983). Etiella sering berperan sebagai pembuka jalan infeksi Apergillus pada kacang tanah (Rachaputi et al., 2002). Kontaminasi aflatoxin pada bahan makanan, termasuk kacang akan membahayakan kesehatan manusia dan hewan ternak.

Petani sampai saat ini lebih banyak tergantung pada penggunaan insektisida untuk mengendalikan penggerek polong dan hasilnya tidak memuaskan. Dikuatirkan aplikasi insektisida yang biasa dilakukan petani pada kacang tanah tidak mengenai sasaran dan bahkan merusak keanekaragaman serangga berguna (misalnya musuh alami) pada ekosistem kacang tanah. Oleh sebab itu diperlukan teknologi pengendalian yang lebih ramah lingkungan dan mudah dipraktekkan petani. Percobaan lapangan dilakukan di dua lokasi (dataran rendah dan dataran tinggi untuk mengevaluasi ketahanan varietas kacang tanah yang telah dilepas oleh Balai Penelitian Pertanian di Indonesia.

\section{METODE PENELITIAN}

Penelitian ini dilakukan pada bulan AgustusNovember 2009. Percobaan lapangan dilakukan di dua lokasi di lahan petani di Desa Air Dingin, Kecamatan Bermani Ulu Raya, Kabupaten Rejang Lebong (ketinggian $900 \mathrm{~m}$ dpl.; jenis tanah Andisol; pH tanah 5,1) dan di Balai Pengkajian Teknologi Ketransmigrasian di Desa Marga Sakti, Kecamatan Padang Jaya (Kuro Tidur), Kabupaten Bengkulu Utara (ketinggian $200 \mathrm{~m}$ dpl.; jenis tanah Ultisol; pH tanah 4,5). Sampel tanah diambil dari kedua lokasi, masing-masing pada lima titik di dalam petak percobaan dan dicampur untuk analisis tanah secara komposit untuk mengetahui $\mathrm{pH}, \mathrm{Al}-\mathrm{dd}$, kandungan N, P, dan K. Tidak ditemukan tanaman inang PPK dalam hamparan luas di lokasi Air Dingin. Petak percobaan berdekatan dengan tanaman jagung dan tanaman sayuran (terong, cabe dan kol bunga). Sebaliknya di lokasi Kuro Tidur petak percobaan berada berdekatan dengan hamparan pertanaman kedelai yang menurut Apriyanto et al. (2009b) merupakan tanaman inang utama dan lebih menarik bagi PPK dibandingkan dengan tanaman kacang tanah.

Sebagaimana telah diuraikan sebelumnya, bahwa dari penelitian yang sudah dilakukan di Bengkulu, (Apriyanto et al., 2009a) varietas Panther dan Sima lebih tahan terhadap PPK dibandingkan dengan varietas lokal dan varietas lainnya. Kedua varietas tersebut diuji ulang, ditambah beberapa varietas yang didatangkan dari Balai Penelitian Tanaman Kacang-kacangan dan Ubi-ubian (Balitkabi) Malang, yaitu varietas Jerapah, Bison, Kancil dan Singa. Varietas lokal digunakan sebagai pembanding. Varietas lokal adalah varietas yang telah lama ditanam petani dari musim ke musim dan tidak diketahui lagi asalnya.

Setiap varietas yang diuji ditanam di lapangan pada petak-petak percobaan berukuran $3 \mathrm{~m}$ x $5 \mathrm{~m}$ dengan jarak tanam $20 \mathrm{~cm} \times 30 \mathrm{~cm}$, masing masing pada 3 petak sebagai ulangan. Pengaturan (peletakan) varietas pada petak-petak percobaan dilakukan dengan mengikuti rancangan acak kelompok lengkap (RAKL). Pengelompokan unit percobaan berdasarkan posisi masing-masing terhadap tanaman pembatas kebun (hedgerow) berupa barisan tanaman pisang dan rumput gajah, blok I paling berjauhan dengan tanaman pembatas dan blok III paling berdekatan dengan tanaman pembatas.

Tanah diolah sempurna (2 kali) dan diberi dolomit sebanyak $0,5 \mathrm{~kg}$ per petak $\left(0,333\right.$ ton ha $\left.{ }^{-1}\right)$ di Air Dingin dan 4,5 kg per petak ( 3 ton ha $\left.{ }^{-1}\right)$. Biji ditanam dengan jarak baris $30 \mathrm{~cm}$ dan jarak lubang tanam dalam baris $20 \mathrm{~cm}$. Setiap lubang ditanam 2 biji di Air Dingin dan 1 biji di Kuro Tidur. Aplikasi Furadan 3G dengan dosis 3 $\mathrm{kg} \mathrm{ha}^{-1}$ dilakukan untuk melindungi biji yang ditanam dan kecambah yang tumbuh dari gangguan semut dan hama lain yang menyerang biji, kecambah atau tanaman muda. Pemeliharaan dilakukan sesuai dengan kebiasaan petani setempat, yaitu penyiangan sebanyak dua kali, pada saat tanaman umur 25 hari dan 50 hari. Pemupukan dilakukan dengan dosis $70 \mathrm{~kg}$ Urea, 125 SP-36, dan 70 $\mathrm{KCl}$ ha $^{-1}$. Separuh dosis Urea dan seluruh SP-36 dan $\mathrm{KCl}$ diberikan pada saat tanam dan sisa Urea diberikan pada tanaman 28 hari setelah taman (HST). Pengendalian hama pemakan daun pada fase pertumbuhan vegatatif dilakukan dengan menggunakan insektisida (Decis dan Curacron) konsentrasi $1 \mathrm{ml} \mathrm{l}^{-1}$ pada dosis $11 \mathrm{ha}^{-1}$.

Variabel yang diamati dan diukur adalah jumlah polong rusak, jumlah larva per tanaman dan jumlah polong baik (tidak rusak) per tanaman dan bobot polong per petak. Pengamatan kerusakan polong dan jumlah 
larva dilakukan pada tanaman umur 63, 77 dan 91 HST pada tanaman sampel, yaitu 10 tanaman yang ditentukan secara acak, tidak mengikutkan tanaman pinggir. Polong rusak akibat terserang larva PPK dihitung. Persen polong rusak dihitung berdasarkan total polong per tanaman. Pada saat panen (umur 91 hari), semua sisa tanaman (setelah diambil sampel) dipanen, jumlah polong yang rusak dihitung dan ditentukan persentase kerusakannya. Polong sehat (baik) ditimbang untuk mengetahui bobotnya. Data dianalisis dengan analisis varian (ANOVA) untuk melihat adanya perbedaan nyata antar varietas, dilanjutkan dengan BNT untuk memisahkan (membedakan) rerata antar varietas untuk semua variabel pengamatan.

\section{HASIL DAN PEMBAHASAN}

Pertumbuhan kacang tanah di kedua lokasi normal, tidak mengalami gangguan cekaman air dan hama pemakan daun. PPK menimbulkan kerusakan pada polong kacang tanah dengan gejala berupa lubang gerekan pada polong dan biji rusak, hilang sebagian atau seluruhnya. Biji yang rusak kebanyakan berwarna hitam karena ditumbuhi cendawan. Biji yang masih baik atau rusak sebagian tetapi embrionya masih baik berkecambah di lapangan (Apriyanto et al., 2008; Apriyanto et al., 2009a) (Gambar 1). Tingkat serangan penggerek polong kedelai (PPK) (\% polong rusak) berbeda nyata pada ke 7 varietas di lokasi Air Dingin, baik untuk jumlah polong terserang $(\mathrm{F}=4,59 ; \mathrm{P}=0,012)$ maupun persentase polong rusak $(\mathrm{F}=4,53 ; \mathrm{P}=0,0126)$. Di lokasi Kuro Tidur, 6 varietas yang ditanam (minus var. Sima) menunjukkan hal yang hampir sama, untuk jumlah polong terserang $(\mathrm{F}=4,98 ; \mathrm{P}=0,0151)$ dan untuk persentase polong rusak $(\mathrm{F}=3,84 ; \mathrm{P}=0,0475)$ (Tabel 1), tetapi tingkat serangannya secara keseluruhan lebih tinggi dibandingkan dengan di lokasi Air Dingin.

Kerusakan polong pada umumnya meningkat berdasarkan umur tanaman (Gambar 2 dan 3). Dengan mengeluarkan varietas Sima karena hanya ada di Air Dingin (tidak ada di Kuro Tidur), maka tingkat serangan PPK berbeda sangat nyata antar kedua lokasi (ANOVA

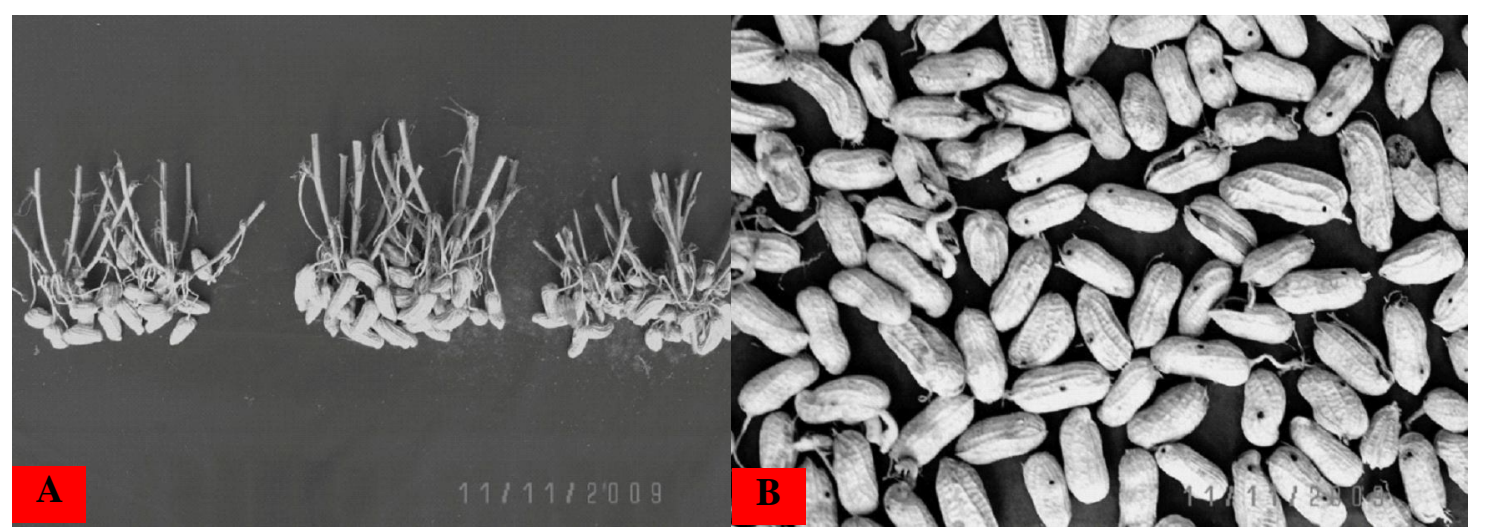

Gambar 1. Polong hasil panen dari petak percobaan. A. Polong bebas PPK, B. Polong terserang PPK (larva telah meningggalkan polong, sering biji yang masih berembrio bekecambah)

Tabel 1. Rerata kerusakan polong per tanaman oleh penggerek polong di dua lokasi

\begin{tabular}{lcccc}
\hline \multirow{2}{*}{ Varietas } & \multicolumn{2}{c}{ Jumlah polong rusak $^{1)}$} & \multicolumn{2}{c}{ Persen polong rusak } \\
\cline { 2 - 5 } & Air Dingin & Kuro Tidur $^{1)}$ & Air Dingin & Kuro Tidur \\
\hline Lokal & $5,9 \mathrm{a}$ & $8,8 \mathrm{a}$ & $26,50 \mathrm{a}$ & $48,82 \mathrm{a}$ \\
Jerapah & $3,2 \mathrm{~b}$ & $7,2 \mathrm{ab}$ & $14,72 \mathrm{~b}$ & $45,30 \mathrm{ab}$ \\
Bison & $3,8 \mathrm{ab}$ & $5,6 \mathrm{bc}$ & $15,77 \mathrm{~b}$ & $37,84 \mathrm{bc}$ \\
Kancil & $2,1 \mathrm{~b}$ & $4,0 \mathrm{c}$ & $10,00 \mathrm{~b}$ & $31,31 \mathrm{bc}$ \\
Panther & $2,3 \mathrm{~b}$ & $4,6 \mathrm{bc}$ & $12,58 \mathrm{~b}$ & $30,08 \mathrm{bc}$ \\
Singa & $1,4 \mathrm{~b}$ & $3,3 \mathrm{c}$ & $9,97 \mathrm{~b}$ & $27,90 \mathrm{c}$ \\
Sima & $1,3 \mathrm{~b}$ & - & $9,04 \mathrm{~b}$ & - \\
\hline
\end{tabular}

1) Angka-angka sekolom yang diikuti huruf yang sama berbeda tidak nyata (BNT; $\alpha=0.05)$. 
petak terbagi, lokasi sebagai petak utama; $F=942,08 ; P$ $=0,0011)$, lebih tinggi di Kuro Tidur dibandingkan dengan di Air Dingin.

Tingkat kerusakan polong nyata lebih tinggi pada varietas lokal dibandingkan dengan pada varietas lain di lokasi Air Dingin, tetapi tidak berbeda nyata dengan varietas Jerapah di lokasi Kuro Tidur. Tingkat kerusakan polong pada varietas Kancil, Panther, Sima dan Singa nyata lebih rendah dibandingkan dengan varietas lokal (Tabel 1), menunjukkan bahwa keempat varietas tersebut lebih tahan dibandingkan dengan varietas lokal. Tidak demikian halnya dengan varietas Jerapah dan Bison, yang tidak berbeda nyata dengan varietas lokal, menunjukkan bahwa kedua varietas tersebut termasuk rentan (susceptible) terhadap PPK. Data tersebut konsisten dengan hasil penelitian sebelumnya (Apriyanto et al., 2009a), meskipun untuk varietas Panther mengalami kerusakan lebih tinggi dibandingkan dengan varietas Sima (berkebalikan dengan yang pernah dilaporkan sebelumnya). Perbedaan ini tidak dapat dijelaskan dan mungkin karena kejadian acak (random chance). Berpedoman pada metode yang digunakan oleh Chiang \& Talekar (1980) cit. Nurdin et al. (1994), maka Sima, Singa, Panther dan Kacil termasuk agak tahan/tahan terhadap PPK, sedangkan varietas jerapah, dan bison termasuk rentan dan varietas lokal termasuk sangat rentan terhadap PPK.

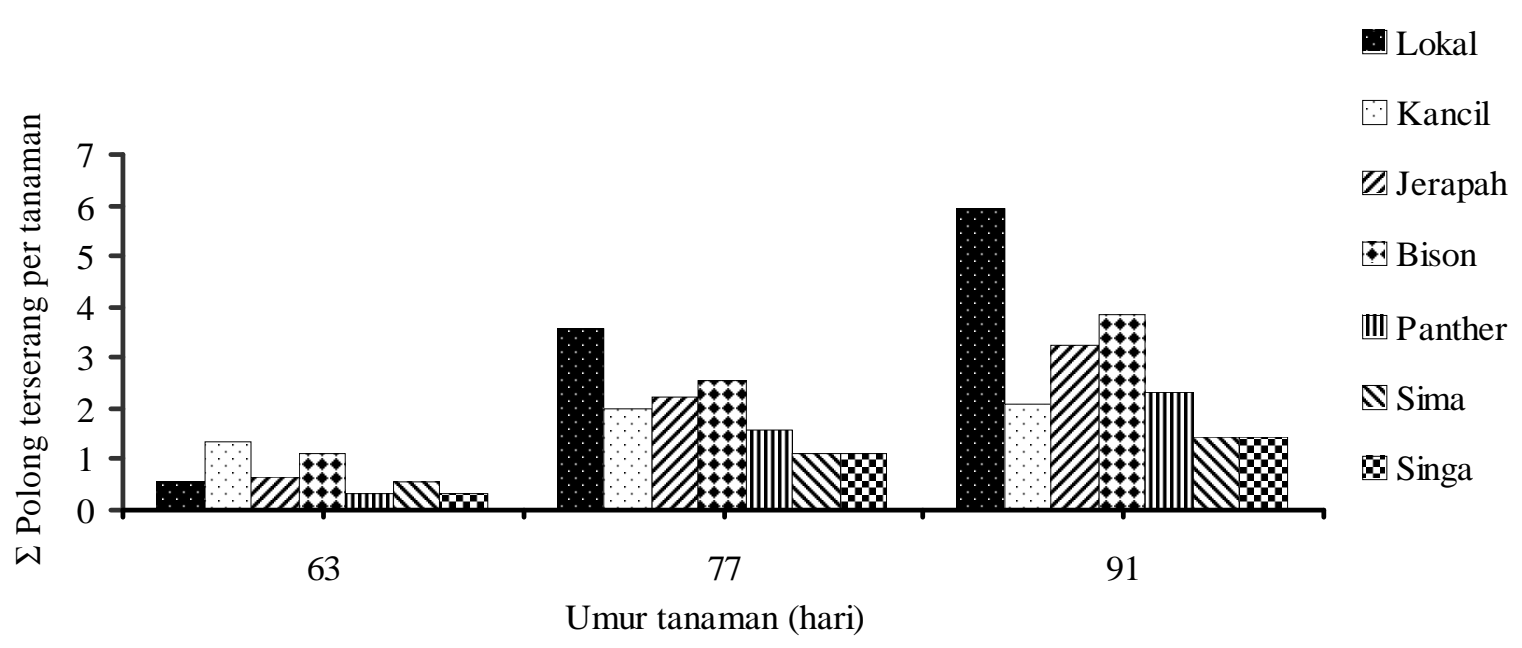

Gambar 2. Perkembangan jumlah polong terserang PPK di lokasi Air Dingin, Rejang Lebong

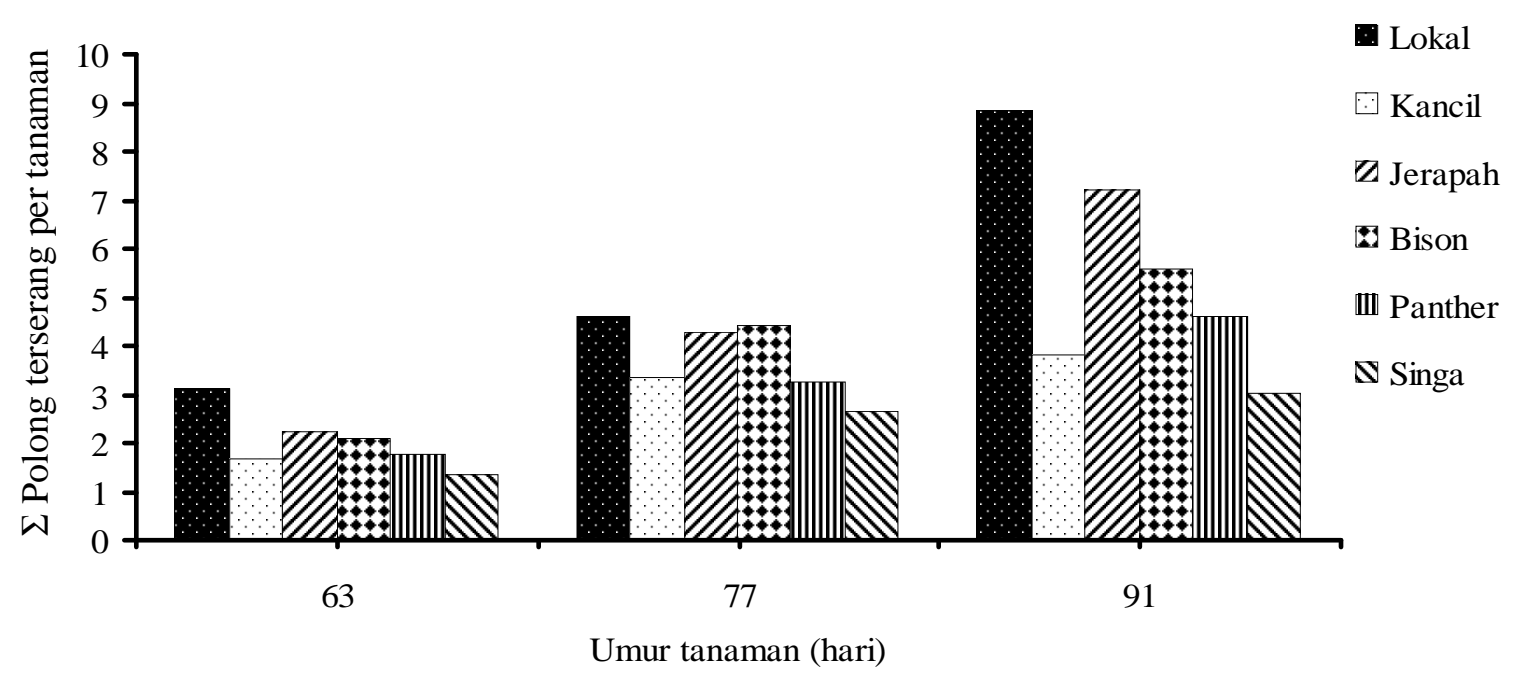

Gambar 3. Perkembangan jumlah polong terserang PPK di lokasi Kuro Tidur, Bengkulu Utara 
Secara visual morfologi polong varietas Sima dan Singa menyerupai varietas Panther, kulitnya bertekstur kasar dan tebal. Varietas Bison, Jerapah, Kacil dan lokal, mempunyai kulit polong bertekstur lebih halus dan lebih tipis. Apriyanto et al. (2009a) melaporkan bahwa struktur kulit polong varietas Panther dan Simpai lebih keras dibandingkan dengan varietas lokal. Argumen lain untuk menjelaskan ketahanan varietas kacang tanah sebagaimana diuraikan Apriyanto et al. (2009a), seperti kandungan atau ketidak seimbangan nutrisi untuk kebutuhan perkembangan larva PPK masih merupakan spekulasi dan perlu dibuktikan kebenarannya. Pembahasan lebih detail perbedaan ketahanan varietas kacang tanah dapat dilihat dalam Apriyanto et al. (2009a), untuk menghindari pengulangan di sini.

Perbedaan ekspresi ketahanan varietas tanaman terhadap herbivor (hama) secara teoritis dapat dipengaruhi oleh lingkungan (misalnya yang relevan dengan penelitian ini adalah ketersediaan unsur hara dalam tanah dan curah hujan), dan populasi hama (Smith, 2005; Sharma, 2009). Kandungan N, P dan K, tersedia lebih tinggi di Air Dingin dibandingkan di Kuro Tidur. Hasil analisis sampel tanah dari petakan percobaan di Air Dingin adalah sebagai berikut: $\mathrm{N}$ total $0,30 \%, \mathrm{P}$ tersedia 10,28 ppm dan K-dd 0,75 me/100 g; sedangkan dari petakan percobaan di Kuro Tidur adalah sebagai berikut: $\mathrm{N}$ total $0,20 \%$, P tersedia 6,68 ppm dan K-dd $0,32 \mathrm{me} / 100 \mathrm{~g}$. Penampilan berbagai jenis hama, misalnya bobot larva dan pupa, jumlah telur yang dihasilkan lebih tinggi pada tanaman yang mengalami gangguan kekurangan unsur hara (Smith, 2005).

Curah hujan mungkin memberi kontribusi pada perbedaan tingkat kerusakan antara kedua lokasi. Meskipun tidak dilakukan pengukuran karena ketidak tersediaan alat pengukur, curah hujan diduga lebih tinggi di Air Dingin dibandingkan dengan di Kuro Tidur karena laporan teknisi lapangan di kedua lokasi menggambarkan hal yang demikian. Di Air Dingin (Rejang Lebong) PPK sering menyebabkan kerusakan pada kacang tanah (Apriyanto et al., 2009a).

Faktor lain yang menyebabkan adanya perbedaan tingkat kerusakan antar kedua lokasi, dan ini mungkin yang paling besar kontribusinya, adalah keberadaan tanaman inang lain didekat petak percobaan. Sebenarnya di lapangan PPK lebih memilih kedelai dibandingkan dengan kacang tanah bila kedua tanaman ini ditanam bersama dan berdekatan (Apriyanto et al., 2009b). Petak percobaan di lokasi Kuro Tidur berdekatan dengan percobaan tanaman kedelai, akan tetapi pengendalian hamanya dilakukan secara intensif dengan insektisida sampai menjelang panen. Sebaliknya, pengendalian hama pada pertanaman kacang tanah hanya dilakukan pada fase pertumbuhan vegetatif dan dihentikan ketika tanaman kacang tanah mulai berbunga. Penggunaan insektisida secara intensif pada tanaman kedelai dapat menyebabkan ngengat PPK terhalau dari tanaman kedelai (yang sebenarnya lebih menarik) dan pindah ke tanaman kacang tanah. Sebaliknya, di Air Dingin tidak ditemukan tanaman inang PPK dalam hamparan di dekat petak percobaan. Jadi populasi larva PPK di Kuro Tidur mungkin juga lebih tinggi dibandingkan dengan di Air Dingin, walaupun data hasil pengamatan larva tidak memperlihatkan hal demikian.

Tingginya tingkat kerusakan polong di Kuro Tidur mungkin menunjukkan penurunan tingkat ketahanan tanaman ketika populasi PPK meningkat. Kerusakan polong yang tinggi seharusnya menggambarkan tingkat populasi larva yang lebih tinggi, tetapi hal ini tidak tampak pada data, karena hanya sedikit larva yang teramati (rerata berkisar antara $0,1-0,4 ; 0,2-0,8$; dan $0-0,2$ larva per tanaman; masing-masing pada pengamatan I, II dan III). Kebanyakan polong yang rusak saat pengamatan sudah ditinggalkan larva. Akan tetapi, tidak mungkin populasi larva yang sama-sama rendah menimbulkan kerusakan yang sangat berbeda, atau menyimpulkan bahwa populasi larva PPK di Kuro Tidur sangat agresif dan kemampuan merusaknya sangat tinggi, sedangkan populasi larva di Air Dingin tidak agresif atau kemampuan merusaknya rendah. Masih banyak pertanyaan yang tidak terjawab dari penelitian ini dan perlu dilakukan penelitian lebih mendalam tentang ekobiologi PPK di lapangan. Untuk studi populasi atau program sampling mungkin diperlukan metode sampling khusus (misalnya quadran) untuk larva PPK pada kacang tanah agar dapat mengukur kepadatan larva, atau sampling stadia telur atau dewasa untuk dapat menghubungkan tingkat kerusakan polong dengan populasi.

Jumlah polong baik (tidak rusak) per tanaman berbeda sangat nyata antar varietas di lokasi Air Dingin $(\mathrm{F}=5,23 ; \mathrm{P}=0,0073)$, demikian juga bobot polong tidak rusak per petak untuk tujuh varietas berbeda sangat nyata $(F=12,84 ; P=0,0001)$. Data untuk enam varietas di Kuro Tidur tidak berbeda nyata, baik untuk jumlah polong baik per tanaman $(\mathrm{F}=2,32 ; \mathrm{P}=0,1208)$ maupun untuk berat polong per petak $(\mathrm{F}=1,89 ; \mathrm{P}=0,1839)$. 
Perbedaan lingkungan mungkin mempengaruhi penampilan pertumbuhan dan produktivitas masingmasing varietas kacang tanah yang dievaluasi pada penelitian ini. Di lokasi Air Dingin, bobot polong baik tertinggi ditunjukkan oleh varietas Panther, tetapi tidak berbeda nyata dengan varietas Jerapah, Bison, Kancil, dan Singa. Bobot polong nyata lebih rendah pada varietas Sima dibandingkan dengan varietas Panther, tidak berbeda nyata dengan keempat varietas lain yang telah disebutkan di atas. Keenam varietas nyata mempunyai bobot polong yang lebih tinggi dibandingkan dengan varietas lokal (Tabel 2). Ukuran dan bobot polong tunggal tidak diukur, tetapi secara visual ukuran polong varietas Panther, Singa dan Sima, lebih besar dibandingkan dengan varietas lainnya, sedangkan ukuran polong varietas lokal paling kecil. Dilihat dari aspek ketahanan dan produksi polong (bobot polong) tampaknya varietas lokal tidak mampu mempertahankan produktivitas dan varietas Panther, Singa, Sima dan Kancil dapat menggantikannya.

Tabel 2. Jumlah polong tidak rusak dan bobot polong basah per petak pada di dua lokasi

\begin{tabular}{lcccc}
\hline \multirow{2}{*}{ Varietas } & \multicolumn{2}{c}{ Jumlah polong baik per tanaman $^{1)}$} & \multicolumn{2}{c}{${\text { Bobot polong per petak }(\mathrm{Kg})^{1)}}^{1)}$} \\
\cline { 2 - 5 } & Air Dingin & Kuro Tidur $^{2}$ & Air Dingin & Kuro Tidur \\
\hline Lokal & $15,3 \mathrm{bc}$ & $9,2 \mathrm{a}$ & $5,24 \mathrm{a}$ & $3,01 \mathrm{a}$ \\
Jerapah & $16,4 \mathrm{bc}$ & $8,7 \mathrm{a}$ & $9,43 \mathrm{bc}$ & $2,83 \mathrm{a}$ \\
Bison & $18,9 \mathrm{c}$ & $9,6 \mathrm{a}$ & $9,07 \mathrm{bc}$ & $3,07 \mathrm{a}$ \\
Kancil & $18,4 \mathrm{c}$ & $9,2 \mathrm{a}$ & $9,49 \mathrm{bc}$ & $3,09 \mathrm{a}$ \\
Panther & $16,1 \mathrm{bc}$ & $10,7 \mathrm{a}$ & $10,36 \mathrm{c}$ & $4,61 \mathrm{a}$ \\
Singa & $14,1 \mathrm{ab}$ & $8,4 \mathrm{a}$ & $8,35 \mathrm{~b}$ & $4,90 \mathrm{a}$ \\
Sima & $10,4 \mathrm{a}$ & - & $9,09 \mathrm{bc}$ & - \\
\hline
\end{tabular}

${ }^{1)}$ Angka-angka sekolom yang diikuti oleh huruf yang sama berbeda tidak nyata (Uji BNT; $\alpha=0,05$ ).

\section{SIMPULAN}

Penggerek polong kedelai merupakan hama penting pada tanaman kacang tanah di Bengkulu baik di dataran rendah maupun di dataran tinggi. Oleh sebab itu perlu perhatian yang serius untuk mengendalikannya. Penelitiaan untuk mengetahui ekobiologinya pada tanaman kacang tanah dan mencari teknologi yang ramah lingkungan sangat diperlukan. Dari penelitian ini diketahui bahwa tanaman kacang tanah varietas Kancil, Panther, Sima dan Singa lebih tahan (resisten) dibandingkan dengan varietas lokal, Jerapah dan Bison, walaupun tingkat ketahanan tersebut menurun di lokasi dataran rendah (Kuro Tidur). Hasil polong baik lebih tinggi pada keempat varietas tahan tersebut dan varietas Jerapah dan Bison dibandingkan dengan varietas lokal di Air Dingin, tetapi tidak berbeda nyata antar semua varietas di Kuro Tidur. Varietas-varietas tahan tersebut dapat direkomendasikan untuk menggantikan varietas lokal, paling tidak di dataran tinggi.

\section{DAFTAR PUSTAKA}

Apriyanto D, Sriwidodo \& Priyatiningsih. 2008. Incidence of soybean pod borer on groundnut (Arachis hypogaea L.) in Bengkulu. Akta Agrosia 11(1): 40-45.

Apriyanto D, Gunawan E \& Sunardi T. 2009a. Resistance of some groundnut cultivars to soybean pod borer Etiella zinckenella Treit.(Lepidoptera: Pyralidae). Jurnal Hama Penyakit Tumbuhan Tropika 9(1): 1-7.

Apriyanto D, Yoga OH \& Mulyadi A. 2009b. Biologi Penggerek Polong Kedelai, Etiella zinckenella Treitschke (Lepidoptera: Pyralidae) dan Pemilihan Inang pada Kedelai dan Kacang Tanah. Makalah disampaikan pada Seminar Nasional Perlindungan Tanaman. Pusat Kajian Pengendalian Hama Terpadu, IPB, Bogor 5-6 Agustus 2009. 
Hill RA, Blankenship PD, Cole RJ \& Sanders TH. 1983. Effect of soil moisture and temperature on postharvest invation of peanut by Aspergillus flavus. Applied and Environ. Microbiol. 45: 628-633.

Kalshoven LGE. 1981. Pests of Crops in Indonesia. P.T. Ichtiar Baru-Van Hoeve, Jakarta.

Kobayashi T \& Oku T. 1980. Sampling lepidopterous pod borers on soybean. Pp. 422-437 In: Kogan M \& Herzog DC, eds. Sampling Methods in Soybean Entomology. SpringerVerlag, NY.

Marwoto, Wahyuni E \& Neering KE. 1991. Pengelolaan Pestisida dalam pengendalian hama kedelai secara terpadu. Monograf Balitas Malang No. 7.
Nurdin F, Artani F \& Sadar. 1994. Reaksi beberapa galur dan varietas kedelai terhadap penggerek polong Etiella spp. Risalah Seminar Balitan Sukarami 3: 105-110.

Rachaputi NR, Wright GC \& Krosch S. 2002. Management practices to minimize preharvest aflatoxin contamination in Australian peanuts. Austr. J. Exp. Agric. 42: 595-605.

Sharma HC. 2009. Biotechnological Approaches for Pest Management and Ecological Sustainability. CRC Press. Boca Raton, LU, USA.

Smith CM. 2005. Plant Resistance to Arthropods Molecular and Conventional Approach. Springer, Dordrecht, The Netherlands. 